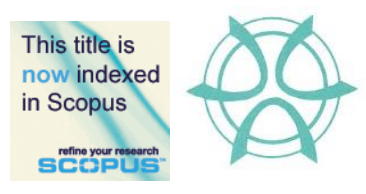

PLANNING MALAYSIA:

Journal of the Malaysian Institute of Planners

VOLUME 16 ISSUE 1 (2018), Page 239 - 250

\title{
VALUER'S BEHAVIOURAL UNCERTAINTIES IN PROPERTY VALUATION DECISION MAKING
}

\author{
Nur Ezra Mohammad ${ }^{1}$, Hishamuddin Mohd Ali $^{2} \&$ Tuti Haryati Jasimin ${ }^{3}$ \\ ${ }^{1,2}$ Faculty of Geoinformation and Real Estate \\ ${ }^{3}$ Razak School of Engineering and Advanced Technology \\ UNIVERSITI TEKNOLOGI MALAYSIA
}

\begin{abstract}
Valuation is often said "an art and science". However, it is well known that valuation is more of an "art" than a "science" in which no two valuers could perhaps arrived at the same value. The disparities in the valuation variance pose a point of concern. This research attempts to identify the behavioural uncertainties during valuation decision making process. The finding reveals that there are six (6) elements of valuer's behavioural uncertainties, which include heuristic and bias, ethical conduct, client influence, valuer's experience and knowledge, availability and accuracy of market data, as well as negligence and professionalism.
\end{abstract}

Keyword: Valuer behaviour, decision making, behavioural uncertainties 
Nur Ezra Mohammad, Hishamuddin Mohd Ali \& Tuti Haryati Jasimin

Valuer's Behavioural Uncertainties in Property Valuation Decision Making

\section{INTRODUCTION}

The valuation outcomes (opinion of value) help property owners which may be corporate, institutional, or financial entities, as well as individuals to make decisions on a property including inheritance, asset sharing, asset allocation, property performance measurement, privatization and commercialization of assets, property sales and purchases as well as investment opportunities (Aluko, Ajayl, \& Amidu, 2004). The complexity in valuation make valuers easily exposed to outside influences. For instance, valuers are often pressured by banks to inflate the value of a property (Agarwal et al., 2015; Gwin \& Maxam, 2002). This, indirectly gives impact to the valuation practices around the world and valuers' credibility. Although certain valuation techniques and methods are used by valuers around the world to derive property values, valuation professionals constantly battle to find a consistency in conducting valuations and ultimately variances in the result or outcome of their valuations do exists (Havard, 2001). The "art" of valuation also creates certain behavioural traits or characteristics in valuer in conducting valuation process that could confound his judgment, which contribute to inconsistency or variance in values. According to Iroham, Ogunbaand and Oloyede (2014), there was evidence to suggest that property valuers are exposed to various assumptions and speculations, emotional uncertainty, heuristics and cognitive biases and errors, negligence (misconduct) and other behavioural issues, which result in their valuation decisions tend to follow trends and clients' influences. In attempting to identify the most significant behavioural uncertainties which affect valuer decision making behaviour, it is important to understand and address the general human behaviour in decision making process. Behavioural uncertainties greatly affect the value arrived at in the property market because they act as hindrances when carrying out valuation and transaction activities (Aliyu, Bello, Kasim, \& Martin, 2014).

In addition, research from the field of cognitive psychology has provided an understanding of how human make decisions. Of particular to valuation is how decision-makers operate in complex environments (under pressure) where the outcome of the task is uncertain. In these situations, humans adopt cognitive short cuts, known as "heuristics", to ease the burden of information processing (Kahneman, Slovic, \& Tversky, 1982). "Heuristics" refers to a situation where a valuer forms a preconceived opinion on the worth of the property being valued and then works to the preconceived answer (as it were) (Akinjare, Iroham, \& Oloke, 2013). It is important to identify the use of heuristics from novice decision making behaviour in order to improve the efficiency of the decision making process (Hardin, 1997). This is due to the tendency of the use of heuristics may lead to biased or inefficient decisions. Another issue, which also may lead to inaccurate values, is valuers' set of knowledge and experience obtained throughout their career. Valuers may be biased by specific knowledge as well as familiarity related to the property, such as previous valuation or the actual 
PLANNING MALAYSIA

Journal of the Malaysia Institute of Planners (2018)

transaction price on the property. Babawale and Omirin (2012), and Havard (2001) agree that valuers' knowledge and experience, as well as familiarity with market are significant influences on valuation accuracy. The level of knowledge and experience significantly affects valuers' decision making behaviour in the valuation of properties. Hence, it is important to acknowledge that valuation is not merely a pure science, but the value is predominately derived from art or soft aspect compared to science (Warren-Myers, 2016), which has potential for inaccuracy, variation and bias on the outcomes.

Earlier studies acknowledged that lack of awareness of behavioural uncertainties of a valuer should be a point of concern because studies discovered that these cause "errors in valuation" (Akinjare et al., 2013; Kucharska-Stasiak, 2013; Wilkens, 2014; Iroham et al., 2014; Warren-Myers, 2015). Valuation is an art, hence the human judgement factor needs to be considered (Akinjare et al., 2013). Thus, this research attempts to undertake behavioural valuation research for local context to indicate the most significant elements of behavioural uncertainties towards valuation decision making.

This research can be a platform in behavioural and psychological knowledge and insights as well as guidelines to the valuation practice. The uncertainty of valuation is not being given much attention by local scholars. To date, only a few articles have been published, which points out the need for undertaking research in behavioural and psychological aspects of valuation practice. Earlier studies were only focusing on identifying the behavioural elements that exist in valuers' behaviour and how those elements affect valuation accuracy. On the contrary, this trans-disciplinary research of understanding valuers' decision making behaviour and what causes such behaviour as well as to curb and enable a different and extensive outlook on valuation practice especially in behavioural aspects. In short, this study provides deeper and wider set of knowledge concerning to how valuers arrived at valuation decisions from the behavioural and psychological aspects.

\section{LITERATURE REVIEW}

Valuation is the estimation of property value at a given point in time. This value reflects the transaction price of real properties in the open market. The role publicly ascribed to the valuer is to deliver a valuation report, which is used by both parties (buyer and seller) to set the sale price of a property at fair market value. Valuers should provide guidance to their clients on the fair market price of properties (Bartke \& Schwarze, 2015). Valuers are supposed to take an objective and neutral stance when conducting valuation in order to determine fair market value. Unfortunately in reality, valuation outcomes are always exposed to uncertainties, which affects the fair market value of properties.

No two valuers are likely to arrive at the same value. However, valuers need to be responsible of their action in order to ensure that they arrived at 
Nur Ezra Mohammad, Hishamuddin Mohd Ali \& Tuti Haryati Jasimin

Valuer's Behavioural Uncertainties in Property Valuation Decision Making

reasonable values that can predict variations in their values and finally may lead to a logical and reliable market situation. As mentioned earlier, one should accept that valuation involves human judgement. It is because each and every type of valuation, by nature, is unsure and uncertain (Aliyu et al., 2014). One of the causes to the existence of uncertainty in valuation is human behaviours (Kucharska-Stasiak, 2013). It is important to address what factors influence valuers decision making process because a reliable valuation depends on valuers' judgments. In order to identify the causes to the unwanted valuation errors (valuation inaccuracy), a consideration on how valuers make decisions and what factors influence their judgment to arrive at opinion of values must be taken into account The study of incorporating behavioural research in valuation accuracy research would permit an expansion of the research focus instead of incorporating the understanding of human judgment, bias and seemingly irrational behaviour, as well as to help in improving our interpretation of the way valuers make decisions and reach reliable CONCLUSION. Earlier studies learned that the critical elements of behavioural uncertainties include (i) heuristic and bias, (ii) ethical conduct, (iii) valuer's experience and knowledge, (iv) client influence, (v) accuracy and availability of market data as well as (vi) negligence and professionalism (Akinjare et al., 2013; Farlow, 2004; Hardin, 1997; Havard, 2001; Levy \& Schuck, 1999; Wilkens, 2014). These are summarised in Table 1 below.

Table 1: The elements of behavioural uncertainties

\begin{tabular}{|c|c|c|c|}
\hline No. & $\begin{array}{l}\text { Elements of } \\
\text { behavioural } \\
\text { uncertainties }\end{array}$ & Description & Variables \\
\hline 1 & $\begin{array}{l}\text { Heuristics } \\
\text { and biases }\end{array}$ & $\begin{array}{l}\text { Heuristic is the use of } \\
\text { simplifying cognitive } \\
\text { shortcuts in solving } \\
\text { complex problems } \\
\text { (Simon, 1978). } \\
\text { - It is a cognitive short cuts } \\
\text { to ease the burden of } \\
\text { information processing } \\
\text { (Kahneman et al., 1982). } \\
\text { The information usually } \\
\text { obtained from valuer's } \\
\text { experience and human } \\
\text { capital. Limited time } \\
\text { frame prompted valuers to } \\
\text { adopt heuristics (Quan \& } \\
\text { Quigley, 1991). }\end{array}$ & $\begin{array}{l}\text { Kahneman et al., } 1982 \\
\text { introduced three types of } \\
\text { heuristics, (i) the } \\
\text { representative heuristic, } \\
\text { (ii) the availability } \\
\text { heuristic, (iii) the } \\
\text { anchoring and adjustment } \\
\text { heuristic; whilst Evans } \\
\text { (1989) introduced (iv) the } \\
\text { positivity heuristic. } \\
\text { Scott, Stumpp \& Xu } \\
\text { (1999) categorised two } \\
\text { general biases, (i) } \\
\text { overconfidence and (ii) } \\
\text { prospect theory. } \\
\text { Farlow (2004) discussed } \\
\text { over-optimism bias as one } \\
\text { of the most important }\end{array}$ \\
\hline
\end{tabular}


PLANNING MALAYSIA

Journal of the Malaysia Institute of Planners (2018)

\begin{tabular}{|c|c|c|c|}
\hline & & $\begin{array}{l}\text { Biases are associated with } \\
\text { heuristic (Salzman \& } \\
\text { Zwinkels, 2013). } \\
\text { Conservatism bias leads to } \\
\text { overestimate and } \\
\text { underestimate of real } \\
\text { market value, valuers } \\
\text { avoid to absorb new } \\
\text { information of relevant } \\
\text { market situation. The use } \\
\text { of heuristic often leads to } \\
\text { bias decisions. }\end{array}$ & $\begin{array}{l}\text { factors in real estate } \\
\text { markets. }\end{array}$ \\
\hline 2 & $\begin{array}{l}\text { Ethical } \\
\text { conduct }\end{array}$ & $\begin{array}{l}\text { RICS (2013), emphasizes } \\
\text { the importance of } \\
\text { professional ethics } \\
\text { because it acts as an } \\
\text { anchor to appropriate } \\
\text { behaviours. It ensures } \\
\text { consistency and clarity } \\
\text { irrespective of changing } \\
\text { factors such as the state of } \\
\text { the economy or business } \\
\text { practices in different } \\
\text { marketplace. } \\
\text { Ethical behaviour is a } \\
\text { human behavioural trait } \\
\text { that would need to come } \\
\text { from the professional } \\
\text { valuers themselves. Ethics } \\
\text { and credibility are the } \\
\text { main reasons for most } \\
\text { valuers not adjusting their } \\
\text { values as requested by } \\
\text { clients (Wilkens, 2014). } \\
\text { Ethics and integrity are } \\
\text { important to fight } \\
\text { corruption (Ssonko, } \\
\text { 2010). }\end{array}$ & $\begin{array}{l}\text { Five standards that should be } \\
\text { demonstrated by valuers } \\
\text { are (i) act with integrity, } \\
\text { (ii) always provide a high } \\
\text { standard service, (iii) act } \\
\text { in a way that promotes } \\
\text { trust in the profession } \\
\text { (honesty), (iv) treat others } \\
\text { with respect, and (v) take } \\
\text { responsibility (RICS, } \\
\text { 2013). }\end{array}$ \\
\hline 3 & $\begin{array}{l}\text { Client } \\
\text { influence }\end{array}$ & $\begin{array}{l}\text { - Uncertainty of valuation } \\
\text { increases due to client } \\
\text { influence (Kucharska- } \\
\text { Stasiak, 2013). } \\
\text { - Valuers make adjustments } \\
\text { on the value after client } \\
\text { interaction or pressure } \\
\text { (Wilkens, 2014). }\end{array}$ & $\begin{array}{l}\text { Three ways of client } \\
\text { influence on valuers; (i) } \\
\text { reward power, (ii) } \\
\text { coercive power, (iii) } \\
\text { expert power and (iv) } \\
\text { information power (Levy } \\
\text { \& Schuck, 1999). }\end{array}$ \\
\hline
\end{tabular}


Nur Ezra Mohammad, Hishamuddin Mohd Ali \& Tuti Haryati Jasimin

Valuer's Behavioural Uncertainties in Property Valuation Decision Making

\begin{tabular}{|c|c|c|c|}
\hline & & $\begin{array}{l}\text { Ethical issues associated } \\
\text { to the willingness of } \\
\text { valuers to adjust their } \\
\text { value as requested by } \\
\text { clients. Valuers with high } \\
\text { integrity have low } \\
\text { tendency to satisfy clients' } \\
\text { interests (Levy \& Schuck, } \\
\text { 2005). } \\
\text { Client-business } \\
\text { relationships urge valuers } \\
\text { to satisfy clients interest } \\
\text { (Shi-Ming, 2002). } \\
\text { Ethical codes recognize } \\
\text { the existence of client } \\
\text { influence and seek to } \\
\text { prevent it (Akinjare et al., } \\
\text { 2013). } \\
\text { Clients believe they have } \\
\text { better knowledge about } \\
\text { property value compared } \\
\text { to valuers due to their } \\
\text { experience in the property } \\
\text { market and managing the } \\
\text { assets (Achu, 2011). }\end{array}$ & \\
\hline 4 & $\begin{array}{l}\text { Valuer's } \\
\text { experience } \\
\text { and } \\
\text { knowledge }\end{array}$ & $\begin{array}{l}\text { Valuer's knowledge and } \\
\text { experience have } \\
\text { significant influences on } \\
\text { valuation accuracy } \\
\text { (Babawale \& Omirin, } \\
\text { 2012). } \\
\text { Majority valuers in } \\
\text { Nigeria are not well } \\
\text { experienced to obtain an } \\
\text { accurate valuations } \\
\text { (Ayedun, Oloyede, \& } \\
\text { Durodola, 2012). } \\
\text { An independent, skilled } \\
\text { and experience valuer } \\
\text { provides reliable advice } \\
\text { and guidance to clients } \\
\text { (Orr, 2013). } \\
\text { Valuers need to } \\
\text { continuously upgrade } \\
\text { their knowledge in the }\end{array}$ & $\begin{array}{l}\text { Three important factors } \\
\text { related to accurate } \\
\text { valuations (i) age, (ii) } \\
\text { experience and (iii) } \\
\text { education, whilst skilled } \\
\text { and independent valuers } \\
\text { are important for reliable } \\
\text { market value (Hoyt et al., } \\
\text { 2002; Orr, 2013). }\end{array}$ \\
\hline
\end{tabular}


PLANNING MALAYSIA

Journal of the Malaysia Institute of Planners (2018)

\begin{tabular}{|c|c|c|c|}
\hline & & $\begin{array}{l}\text { valuation practice (Boyd } \\
\& \text { Irons, 2002). }\end{array}$ & \\
\hline 5 & $\begin{array}{l}\text { Availability } \\
\text { and accuracy } \\
\text { of market } \\
\text { data }\end{array}$ & $\begin{array}{l}\text { Valuation accuracy } \\
\text { greatly depends on the } \\
\text { quantity and quality of } \\
\text { available market data } \\
\text { (Babawale \& Omirin, } \\
\text { 2012). } \\
\text { Valuation will be } \\
\text { inaccurate when } \\
\text { comparable data are } \\
\text { limited especially in a } \\
\text { sluggish market (Havard, } \\
\text { 2001). } \\
\text { Lack of data can directly } \\
\text { affect valuation process } \\
\text { and cause valuation } \\
\text { uncertainty (Ajibola, } \\
\text { 2011; Aliyu et al., 2014). } \\
\text { The complexity to access } \\
\text { and to analyse market } \\
\text { information raises issue in } \\
\text { estimating fair market } \\
\text { value (Ilsjan \& Kask, } \\
\text { 2006). } \\
\text { Lack of reliable databank } \\
\text { contributes to inaccurate } \\
\text { professional valuation } \\
\text { advice (Ajibola, 2011; } \\
\text { Aluko, 2007). }\end{array}$ & $\begin{array}{l}\text { Factors contribute to } \\
\text { difficulty to access market } \\
\text { information data are (i) } \\
\text { confidentiality constraints, } \\
\text { (ii) lack of trust among } \\
\text { professional valuers (tend } \\
\text { to be secretive) and (iii) } \\
\text { conservative attitude. }\end{array}$ \\
\hline 6 & $\begin{array}{l}\text { Negligence } \\
\text { and } \\
\text { professionalis } \\
\text { m }\end{array}$ & $\begin{array}{l}\text { - Negligence is one of } \\
\text { behavioural uncertainty } \\
\text { that can be found in the } \\
\text { valuation process } \\
\text { (Hishamuddin et al., } \\
\text { 2016). } \\
\text { - Australian valuers are } \\
\text { required to "exercise a } \\
\text { reasonable standard of } \\
\text { professional care" as the } \\
\text { basis to assess negligence } \\
\text { (Boyd \& Irons, 2002). } \\
\text { All aspects of valuation } \\
\text { exercise must be } \\
\text { undertaken in a competent }\end{array}$ & $\begin{array}{l}\text { - Negligence can occurr in } \\
\text { two ways (i) error in } \\
\text { surveys and (ii) error in } \\
\text { procedures (Havard, } \\
\text { 2001). }\end{array}$ \\
\hline
\end{tabular}


Nur Ezra Mohammad, Hishamuddin Mohd Ali \& Tuti Haryati Jasimin

Valuer's Behavioural Uncertainties in Property Valuation Decision Making

manner to avoid

negligence (Boyd \& Irons,

2002).

- Valuers unprofessional

behaviour leads to

overstate the defensible

property values (Ayuthaya

\& Swierczek, 2014; Levy

\& Schuck, 1999)

\section{RECOMMENDED BEHAVIOURAL APPROACHES IN OVERCOMING THE DISCREPANCIES IN VALUATION}

Earlier studies have shown that major issues facing the valuation industry, especially in the behavioural valuation aspect, are the lack of guiding standards, the unavailability of databank consisting of analysed market information, lack of training courses for valuers such as continued professional development programmes, lack of standardisation of valuation methodology used, and lack of ethical guidelines enforcement in valuation practice. For the purpose of this research, the issues highlighted in property valuation are grouped into four main categories, which are (i) institutional, (ii) informational, (iii) technical, and (iv) ethical issues.

As mentioned by Kucharska-Stasiak (2013), in order to eliminate the valuation uncertainties, it is important to seek ways of eliminating the systematic (behavioural) ones. Academics and professionals have been striving to overcome the discrepancies in valuation, and several recommendations have been suggested to curb the issues. One should accept that the uncertainties in valuation practice must be openly acknowledged professionally and publicly. The inconsistency and uncertainty can be minimized if the professional institutions, member firms and the academics are willing to collaborate in curbing the issues facing the industry.

In order to ensure that valuers comply with the duty of reasonable care (as being practiced by Australian courts), it is essential that valuers continuously upgrade their knowledge and competency (Boyd \& Irons, 2002). The professional organizations also need to play important roles by assisting the valuers to adhere to the standards of the professional practice. The organizations also should provide a continuing professional development programme to ensure the competency of members abreast with the best valuation practices (Bello \& Bello, 2007). Mahoney (1993) concludes that the important role played by professional organizations and the valuers themselves is crucial. He highlighted that independent of valuers' opinion, honesty in delivering valuation exercise and competency are the elements that should be considered by both professional organizations and valuers to avoid negligence and client influence. Seminars, workshops or conferences can be alternatives to promote continuous education 
PLANNING MALAYSIA

Journal of the Malaysia Institute of Planners (2018)

programmes, particularly by those with specialist skills and knowledge. A more experience valuers may share their experience and knowledge with the participants. Besides, through the exposure of valuers to the opportunities for such structured knowledge development and experience, valuers will inherently progress to intuitive knowledge and creation of heuristics (Warren-Myers, 2016).

The lack of property market data and lack of standardisation of valuation practice are also causing unreliable valuation outcomes (Adegoke, Olaleye, \& Oloyede, 2013; Ajibola, 2011; Narayan, Biswas, \& Sahib, 2017). Therefore, there is a need to provide a good database and to develop computerised valuation technique. There is also a need to improve and consistently review the current national standards to ensure that they are in line with the international standards of best practices. An enforcement of high ethical standards, independence and professionalism are needed to reduce the valuers' exposure to claims of negligence.

The professional organizations are responsible to educate the valuers, mortgagers and the general public on the benefits of valuation standards, the need for their strict compliance, and adherence to normative valuation objectives (Amidu, Aluko, \& Hansz, 2008). This is to ensure that parties who have interests in valuation exercise are aware and acknowledge the nature of valuation practice. It is important to enlighten the parties involved to avoid the influence (or pressure) of clients as well as to promote valuers to work independently because clients' lack of understanding of valuation principles is another contributory factor on the existence of client influence (Achu, 2011). Additionally, the regulatory bodies need to set up mechanism to constantly monitor the activities of valuers to ensure they strictly comply with the code of conduct (Amidu \& Aluko, 2007; Shi-Ming, 2002). A more stringent policy on professional valuer entry qualifications can also help (Wilkens, 2014). Meanwhile, any valuers violating professional ethics and regulations should be held accountable and penalties should be imposed such as formal caution, note of warning, suspension of qualification and qualification withdrawal. All these should be established in standardised manner by the regulatory bodies (Aliyu et al., 2014). 
Nur Ezra Mohammad, Hishamuddin Mohd Ali \& Tuti Haryati Jasimin

Valuer's Behavioural Uncertainties in Property Valuation Decision Making

\section{CONCLUSION}

This research has presented a review of behavioural aspects in property valuations. The issues of behavioural uncertainties in the property valuation need to be addressed because the disparity in valuation results become a problem to practitioners and the public (clients). This research has laid down the six elements of behavioural uncertainties that have significantly affect property valuation decision making. It has also outlined several recommendation on how this issue could be ameliorated.

\section{REFERENCES}

Achu, K. (2011, January). Do clients influence valuations carried out for financial reporting purposes? Some evidence from Malaysia. In 17th Pacific Rim Real Estate Society Conference, January 16-19, 2011, Gold Coast, Australia.

Adegoke, O. J., Olaleye, A., \& Oloyede, S. A. (2013). A study of valuation clients perception on mortgage valuation reliability. African Journal of Environmental Science and Technology, 7(7), 585-590.

Agarwal, S., Yao, V., Mae, F., Durant, T., Faulkner, M., Sapienza, P., \& Qian, W. (2015). Collateral valuation and borrower financial constraints: Evidence from the residential real estate market. Management Science, 61(9), 2220-2240.

Ajibola, M. (2011). Importance of accessibility to reliable data for real estate practice. Mediterranean Journal of Social Sciences, 2(2), 223-231.

Akinjare, O. A., Iroham, O. C., \& Oloke, O. C. (2013). Valuation discrepancies in the value opinion of professional valuers' in Lagos, Nigeria. International Journal of Economy, Management and Social Sciences, 2(6), 272-276.

Aliyu, A. A., Bello, M. U., Kasim, R. B., \& Martin, D. (2014). Intangible elements of uncertainty in property valuation: Theoretical underpinning. Journal of Economics and Sustainable Development, 5(17), 57-63.

Aluko, B. T. (2007). Examining valuer's judgement in residential property valuations in metropolitan Lagos, Nigeria. Property Management, 25, 98-107.

Aluko, B. T., Ajayl, C. A., \& Amidu, A. R. (2004). The estate surveyors and valuers and the magic number: A point estimate or a range of value? International Journal of Strategic Property Management, 8(3), 149-162.

Amidu, A. R., Aluko, B. T., \& Hansz, J. A. (2008). Client feedback pressure and the role of estate surveyors and valuers. Journal of Property Research, 25(2), 89-106.

Amidu, R., \& Aluko, B. T. (2007). Client influence on valuation: perceptual analysis of the driving factors. International Journal of Strategic Property Management, 11, 77-89.

Ayedun, C., Oloyede, S., \& Durodola, O. (2012). Empirical study of the causes of valuation variance and inaccuracy in Nigeria. International Business Research, 5(3), 71-80.

Ayuthaya, N. P., \& Swierczek, F. W. (2014). Factors influencing variation in value and investors confidence. IOSR Journal of Business and Management, 16(5), 41-51. 
Babawale, G. K., \& Omirin, M. (2012). An assessment of the relative impact of factors influencing inaccuracy in valuation. International Journal of Housing Markets and Analysis, 5, 145-160.

Bartke, S., \& Schwarze, R. (2015). The economic role of valuers in real property markets. UFZ Discussion Papers 13/2015. Helmholtz Centre for Environmental Research (UFZ), Division of Social Sciences (ÖKUS).

Bello, M. O., \& Bello, V. A. (2007). The influence of consumers behavior on the variables determining residential property values in Lagos, Nigeria. American Journal of Applied Sciences, 4(10), 774-778.

Boyd, T., \& Irons, J. (2002). Valuation variance and negligence: The importance of reasonable care. Pacific Rim Property Research Journal, 8(2), 107-126.

Farlow, A. (2004). Part One Uk House Prices : a, (January), 1-22.

Gwin, C. R., \& Maxam, C. L. (2002). Why do real estate appraisals nearly always equal offer? A theoretical justification. Journal of Property Investment \& Finance, 20(3), 242-253.

Hardin, W. G. (1997). Heuristic use, credit constraints and real estate lending. Journal of Property Valuation and Investment, 15(3), 245-255.

Havard, T. (2001). Valuation reliability and valuer behaviour. RICS Foundation Research Paper, 4(1), 1-47.

Ilsjan, V., \& Kask, K. (2006). Practical issues in valuation of real properties for accounting purposes. Retrieved from http://www.emselts.ee/konverentsid/EMS2006/2_Rahandus_ja_pangandus/Ver onika_Ilsjan.pdf

Iroham, C. O., Ogunba, O. A., \& Oloyede, S. A. (2014). Effect of principal heuristics on accuracy of property valuation in Nigeria. Journal of Land and Rural Studies, 2(1), 89-111.

Kahneman, D., Slovic, P., \& Tversky, A. (Eds). (1982). Judgment under uncertainty: Heuristics and biases. Cambridge: Cambridge University Press.

Kucharska-Stasiak, E. (2013). Uncertainty of property valuation as a subject of academic research. Real Estate Management and Valuation, 21(4), 17-25.

Levy, D., \& Schuck, E. (1999). The influence of clients on valuations. Journal of Property Investment \& Finance, 17(4), 380-400.

Levy, D., \& Schuck, E. (2005). The influence of clients on valuations: The clients' perspective. Journal of Property Investment \& Finance, 23(2), 182-201.

Mahoney, P. (1993). Professional negligence and indemnity. Journal of Valuation, 8(1), 38-52.

Narayan, S., Biswas, S., \& Sahib, L. (2017, March). Issues facing standardisation of property valuation practices: a case study of Suva, Fiji. In 2017 World Bank Conference on Land and Poverty. March 20-24, 2017, Washington DC.

Orr, S. (2013). Unlisted Investments - the quality of the valuation process as important as the quality of the asset the valuation of unlisted assets should Unlisted Investments - the quality of the valuation process as important as the quality of, (August), 1-3.

Quan, D. C., \& Quigley, J. M. (1991). Price formation and the appraisal function in real estate markets. Journal of Real Estate Finance and Economics, 4(2), 127-146. 
Nur Ezra Mohammad, Hishamuddin Mohd Ali \& Tuti Haryati Jasimin

Valuer's Behavioural Uncertainties in Property Valuation Decision Making

Salzman, D. A, \& Zwinkels, R. C. J. (2013). Behavioural real estate. https://doi.org/10.2139/ssrn.2289214

Scott, J., Stumpp, M., \& Xu, P. (1999). Behavioral bias, valuation, and active management. Financial Analysts Journal, 55(4), 49-57.

Shi-Ming, Y. (2002). Client pressure in residential valuations - Evidence from Singapore. Retrieved

from http://prres.net/Papers/Shi_Ming_Client_Pressure_in_Residential_Valuations.p df

Ssonko, D. K. W. (2010, April). Ethics, accountability, transparency, integrity and professionalism in the public service: the case of Uganda. In Capacity Building Workshop for Public Sector Human Resource Managers in Africa on "Strengthening Human Resource Capacities for the Achievement of the Millennium Development Goals and Africa's Development. April 12-16, 2010, Cotonou, Republic of Benin.

Warren-Myers, G. (2016). Sustainability evolution in the Australian property market. Journal of Property Investment \& Finance, 34(6), 578-601.

Wilkens, L. (2014). Client influence on valuer behaviour in South Africa - Nature, prevalence and consequences (Minor dissertation). University of Cape Town, South Africa. 